\title{
Âl-i İmrân 36. Âyette Geçen ‘Erkek Kız Gibi Değildir’ i̇bâresi Hakkındaki Yorumlara Dair Bir Değerlendirme
}

\author{
Avnullah Enes Ateş \\ Doç. Dr., Bilecik Şeyh Edebali Üniversitesi (ROR ID: 00dzfx204) \\ İslami İlimler Fakültesi, Tefsir Anabilim Dalı \\ Associate Professor, Bilecik Şeyh Edebali University, Faculty of Islamic Sciences \\ Department of Qur'anic Exegesis \\ Bilecik/Turkey \\ enes.ates@bilecik.edu.tr \\ ORCID: 0000-0002-4909-9203
}

\section{Adnan Arslan}

Doç. Dr., Bilecik Şeyh Edebali Üniversitesi (ROR ID: 00dzfx204)

İslami İlimler Fakültesi, Arap Dili ve Belagati Anabilim Dalı

Associate Professor, Bilecik Şeyh Edebali University, Faculty of Islamic Sciences

Department of Arabic Language and Rhetoric

adnan.arslan@bilecik.edu.tr

Bilecik/Turkey

ORCID: 0000-0002-3989-6612

\section{An Evaluation of the Interpretations of the Qur'anic Utterance 'No Male child could ever have been like this Female'}

\section{Abstract}

Understanding the Qur'ān's intended meanings depends on accurately pinpointing the denotations of the words that make up the verses as the words in the Qur'ān come with different denotations. There is a hierarchy developed based on the covertness of the intended meanings. Within this hierarchy, there are some words with multiple meanings. These are called mushkil (problematic). The most distinctive feature of such words is that they are open to disputes and different interpretations. One of these is the 36th verse of Al-'Imran. Tafsirs discussed whom the utterance "No male child could ever have been like this female" in this verse belongs to, whether any of these genders is superior to the other and which gender is superior if superiority is the case. This study brought together different perspectives on how the aforementioned verse has been interpreted so far, particularly based on main classical tafsirs, and it examined the reasons for these interpretations. The original commentaries on

Intihal Taraması/Plagiarism Detection: Bu makale intihal taramasından geçirildi/This paper was checked for plagiarism Etik Beyan/Ethical Statement: Bu çalışmanın hazırlanma sürecinde bilimsel ve etik ilkelere uyulduğu ve yararlanılan tüm çalışmaların kaynakçada belirtildiği beyan olunur/It is declared that scientific and ethical principles have been followed while carrying out and writing this study and that all the sources used have been properly cited (Avnullah Enes Ateş, Adnan Arslan).

Geliş/Received: 17 Mayı/May 2021 | Kabul/Accepted: 06 Eylül/September 2021 | Yayın/Published: 20 Eylül/September 2021 Atıf/Cite as: Avnullah Enes Ateş, Adnan Arslan, “Âl-i İmrân 36. Âyette Geçen ‘Erkek Kız Gibi Değildir' ỉbâresi Hakkındaki Yorumlara Dair Bir Değerlendirme = An Evaluation of the Interpretations of the Qur'anic Utterance 'No Male child could ever have been like this Female”', Eskiyeni 44 (Eylül/September 2021), 569-584. https://doi.org/10.37697/eskiyeni.938270 CC BY-NC 4.0 | This paper is licensed under a Creative Commons Attribution-NonCommercial License 
the utterance generally focus on two views. Firstly, there are ontological advantages of being a male with respect to serving for religious temples. Menstruation and puerperium are obstacles that prevent women from being in a temple, whereas the man is free of them and has the necessary physical strength to serve for it. Since such service would entail contact with men who regularly come to the temple, being a female is not appropriate for it. While there is no problem for males to be together with other males in congregation, it is not the case for females. Secondly, Hannah favored the girl bestowed upon her above a boy. According to this, Mary's mother said, "A boy was what I wanted, but this girl is a gift that God has given me. The boy I had wanted could never have been like this female God gave me." According to such an interpretation, Mary's mother is a wise woman who knows that what God has given her is better than what she had wanted for herself. Globally considered, it is stated that each of these interpretations has a scientific basis in general, and that it is not possible to make a definite judgment because the phrases and clauses are likely to have multiple meanings. However, the present study offers the following interpretation about the utterance in question: It gives a "lesson of surrender". It is more appropriate for the purpose of "tawhid and tawakkul" of the Qur'ān for Mary's mother to submit to the will of Allah when she gives birth to a girl although she wishes for a boy in her heart, and that she believes there is goodness in the female child bestowed upon her. This is because the Qur'ān-from the beginning to the end-repeatedly gives the lesson of "acceptance and tawakkul". It is also possible that the Qur'ān offered us the thought or yearning of a woman who gives birth to a daughter while wishing for a son that the son is more gifted for some reason. However, this is not the perspective favored in this study.

\section{Keywords}

Tafsīr, Mushkil, Hannah, Girl, Boy

\section{Âl-i İmrân 36. Âyette Geçen ‘Erkek Kız Gibi Değildir’ İbâresi Hakkındaki Yorumlara Dair Bir Değerlendirmesi}

\section{Öz}

Kur'ân'ın kastedilen anlamlarının anlaşılması öncelikle âyetleri oluşturan lafızların delâletlerini doğru tespit etmeye bağlıdır. Zira Kur'ân'da yer alan lafızların anlamlarına delâletleri farklılık arz eder. Maksûd anlamlarının kapalılıklarına göre bir hiyerarşi vardır. Bazı lafızlar birden fazla anlama muhtemeldir. Bunlara müşkil denilir. Müşkil lafızların en belirgin özelliği ihtilafa, farklı anlayışlara kapısının açık olmasıdır. Birden çok anlama gelmesi muhtemel olan bu âyetlerden birisi de Âl-i İmrân sûresinin 36. âyetidir. Bu Âyette geçen meâlen "Erkek kız gibi değildir." ibaresinin kime ait olduğu, erkek ve kız arasında bir üstünlügün söz konusu olup olmadığı, böyle bir üstünlük varsa bunun hangi cinsiyete ait olduğu vb. tefsirlerde tartışılmıştır. Bu çalışmada mevzubahis âyetin, belli başlı klasik tefsirlerden başlayıp günümüze kadar nasıl yorumlandığına dair farklı görüşler bir araya getirilmiş ve bu yorumların gerekçeleri incelenmiştir. İbare hakkında yapılan özgün tefsirler genel olarak iki görüş etrafında toplanmaktadır. Birincisi: Mabedin hizmetinde bulunma hususunda erkek olmanın ontolojik üstünlükleri bulunur. Erkek hayız, nifas gibi mabette bulunmaya mâni olan engellerden halidir ve mabedin hizmetini görmek için gerekli fiziki güce sahiptir. Mabede devam eden erkeklerle ihtilat etme mecburiyeti olacağı için bu içli dışlı oluşa kadınlık manidir. Erkeğin diğer erkek cemaat ile bir arada bulunmasında herhangi bir sakınca yokken kadın hakkında ise durum öyle değildir. İkincisi: Hanne kendisine bahşedilen kızı erkeğe üstün tutmuştur. Bu yoruma göre Hz. Meryem'in annesi şöyle demiştir: "İstediğim erkekti. Fakat bu kız ise Allah'ın bana bahşettiği bir ihsan. İstediğim olan erkek, Allah’ın bana bahşettiği kız gibi değildir.” Böyle bir yoruma 
göre Meryem'in annesi, Allah'ın kendisine verdiği şeyin kendisi için istediği şeyden daha hayırlı olduğunu bilen marifet ehli bir kadındır. Sonuç olarak bu yorumların her birinin genel anlamda ilmi bir mesnede dayandığı ve lafız ve terkiplerin birden fazla anlama muhtemel olmasından dolayı da kesin bir yargıda bulunmanın mümkün olmadığı belirtilmiștir. Fakat çalışmanın ibare hakkında şöyle bir değerlendirmesi olmuştur: İbare, "teslimiyet dersi" vermektedir. Hz. Meryem'in annesinin, gönlünde erkek çocuğu olduğu halde kız doğurduğunda Allah'ın takdirine teslimiyet göstermesi ve kendisine bahşedilen kız çocuğunda büyük bir hayır var olduğuna inandığını belirtmesi Kur'ân'ın "tevhît ve tevekkül” maksadına daha uygundur. Zira Kur'ân başından sonuna kadar defalarca kazaya rıza, Allah'ın lütfuna teslim dersi vermiştir. Erkek beklerken kızı olan bir kadının erkek çocuğunun herhangi bir sebeple daha meziyetli olduğu gibi bir düşüncesini yahut tahassürünü Kur'ân'ın bizlerle paylaşmış olması da muhtemeldir. Fakat çalışmanın tercihi görüş bu değildir.

\section{Anahtar Kelimeler}

Tefsir, Müşkil, Hanne, Kız Çocuğu, Erkek Çocuğu

\section{Giriş}

Kur'ân'ın maksûd anlamlarının anlaşılması öncelikle âyetleri oluşturan lafızların delâletlerini doğru tespit etmeye bağlıdır. Zira Kur'ân'da yer alan lafızların anlamlarına delâletleri farklılık arz eder. Nitekim lafızların doğrudan zâhirine bakmakla birtakım anlamlar ortaya çıkarken, bu anlamlardan hangisinin kastedilmiş olacağ hususunda söz konusu lafızların sevk ediliş nedeninin bilinmesi gibi harici delil ve karinelerle tespit çalışması yapılır ve bir anlam tebarüz eder. Lafızların ilk anlama delaletine zâhir, ikinci delaletine de nas denilmiştir. Bu tür lafizlardan anlaşılan anlamlarla amel etmek zorunludur. Ne var ki bu lafızlar farklı tevillere de açıktır. Maksûd manaya delâleti bakımından bunlardan daha kuvvetli iki lafız türü daha vardır ki biri müfesser, diğeriyse muhkemdir. Müfesser, şâri‘ (kanun koyucu) tarafından önceden icmâl edilen (kapalı bırakılan) ve daha sonra bizzat kendisi tarafından anlamı açıklanan lafizlardır. Bu lafızların tevile ihtimali bulunmaz. Muhkem de müfesser ile aynı niteliğe sahip olmakla birlikte aralarında şu nüans vardır: Müfesser lafizlar, Hz. Peygamber hayattayken nesih ihtimali taşır, muhkemler ise nesih ihtimali taşımazlar. Bu açıdan muhkem lafızlar, konuyla ilgili son söylenen bir hükmü veyahut neshe konu olmayan bir anlamı içerirler. ${ }^{1} \mathrm{Ne}$ var ki Hz. Peygamber'in vefatıyla birlikte nesih durumu ortadan kalktığı için bütün müfesser denilen lafızlar muhkem statüsü kazanırlar. ${ }^{2}$

Lafızların, mezkûr delâletlerine mukabil, maksûd anlamlarının kapalılıklarına göre de bir hiyerarşi vardır. Lafzın kendi siygasından kaynaklı olmayıp, ârızî bir nedenle anlamı kapalı kalan lafızlara hafî denilir. Asılda bunlar, lafzın anlam kapsamına girip girmediği konusunda zihnin tereddüde düştüğü lafızlardır. Örneğin "hırsız" anlamına gelen السارق (es-sârik) isminin kefen soyguncusunu ya da kapkaççıyı kap-

Ebû Zeyd Abdullāh (Ubeydullāh) b. Muhammed b. Ömer b. Îsâ Debûsî, Takvîmu'l-edille fí usûli'l-fikh, thk. Halil Muhyiddîn el-Meys (Beyrut: Dâru'l-Kütübi'l-'ílmiyye, 1421/2001), 117.

2 Buna muhkem li ğayrihî denilmektedir. Detaylı bilgi için bk. Ebû Abdillâh Muhammed b. İsmâîl b. İbrâhîm el-Cu'fî el-Buhârî, Keşfu'l-esrâr şerhu Usûli'l-Bezdevî (Beyrut: Dâru'l-Kitâbi'l-İslâmî, ts.), 1/51. 
samına alıp almaması konusundaki kapalılık hafî olarak değerlendirilir. Burada lafzın kendi anlamı olan hirsıza delaletinde bir kapalılık yoktur. ${ }^{3}$ Ancak kapsamına diğer zikredilenlerin girmesi konusundaki durum lafzın hafî olarak değerlendirilmesini sağlamıştır. Ârızî ifadesiyle kastedilen budur. Diğer bazı lafızlar da vardır ki bunlar birden fazla anlama muhtemeldir. Bunlara da müşkil denilir. ${ }^{4}$ Müşkiller; kendileriyle kastedilen anlam ile diğer muhtemel anlamların birbirine karıştığı ve bu karışıklığın ancak dikkatli bir düşünme ve delil ile çözülebildiği lafız türleridir. "Kadınlarınız sizin için tarla gibidir. O halde tarlanıza nasl isterseniz girin." âyetinde bizim "nasıl" diye çevirdiğimiz iُ kelimesi için müşkil lafız denilmiştir. Zira bu lafzın "nereden”, “nasıl”, "ne zaman" olmak üzere üç anlamı bulunur. Bu anlamlardan hangisinin kastedildiği lafızdan hareketle bilinebilecek bir durum değildir. Kadınların tarlaya benzetilmesi ile tarladan amaçlananın ürün elde etmek olması arasında bir bağ kurularak, ayetten, girilen yerin çocuğun doğacağı yer olması kaydıyla kadınlarla farklı keyfiyetlerde ilişkinin mübâhlı̆̆ının kastedildiği söylenmiştir. ${ }^{7}$ Lafızların kapalılık hiyerarşisi bakımından bu iki türden daha kapalı olan mücmel ve müteşâbih lafızlar vardır. Mücmeller, söyleyeninin beyanı olmaksızın manası anlaşılamaz nitelikteki lafızlardır. Bu tür lafızları söyleyeni açıkladığında müfesser kimliği kazanırlar. Müteşâbihler ise genel kabule göre hiçbir şekilde anlamı anlaşılamaz türdeki lafızlara denilir. Mukatta'a harfleri, Allah'ın sıfatları gibi hususların bu kapsamda olduğu söylenmektedir. Bazılarına göreyse müteşâbihler ancak ilimde rüsûha ermiş âlimler tarafindan bilinebilecek nitelikteki lafızlardı. ${ }^{8}$

Çalışmamızda inceleme konusu edeceğimiz müşkil lafızların en belirgin özelliği ihtilafa, farklı anlayışlara kapısının açık olmasıdır. Muhtelif kabiliyet ve kavrayış kapasitesine sahip olan tüm insanlar için onlar, bambaşka manalara muhtemel âyetlerdir. Maksadı, Allah'ın muradını keşfetmek gibi samimi niyete sahip olan kimseler bu âyetlerin tefsirinde sahip oldukları âlet ilimlerine başvururlar. Zira keşfettim, buldum, ulaştım kabilinden manaların Kur'ân'ın ifade tarzına göre kastedilmiş olabileceğinin bir ölçütü olmalıdır. Isște bu ölçütlerden birisi de Ulûm-u Arabiyye denilen sarf, nahiv, meânî beyân, bedî gibi ilimlerdir. Ayrıca âyetlerin lafzi ve tarihi bağlamı gibi unsurlar da müşkil âyetlerin maksatlarının ortaya çıkmasına yardımcı olacaktır. Bunun için âyetlerin nüzul sebepleri, tarihleri, diğer âyetlerle münasebetleri ve konuyla ilgili rivayetler ortaya konulmalıdır. Bu ilimlerin kriterleri kullanılarak ulaşılan sonuçlar Arap dili ve Kur'ân ilimleri çerçevesince onaylanmış olur. Aksi halde Kur'ân husu-

Ebû Alî Ahmed b. Muhammed b. İshâk eş-Şâşî, Usûlü’ş-şaş̧î (Beyrut: Dâru'l-Kitâbi'l-'Arabî, ts.), 80.

Şâşî, Usûlü'ş-Şâş̧, 81.

Ebû Abdillâh Radiyyüddîn Burhânü'l-İslâm Muhammed b. Muhammed es-Serahsî, Usûlü’s-Serahsî (Beyrut: Dâru'l-Ma'rife, ts.), 1/168.

el-Bakara 2/223.

7 Hüsâmüddîn Hüseyn b. Alî b. Haccâc el-Buhârî es-Siğnâkî, el-Kâfi şserhu'l-Bezdevî, thk. Fahruddîn Seyyid Muhammed Kānit (Beyrut: Mektebetürr-Rüşd, 1422/2001), 1/233.

8 Safiyyuddîn Abdülmü'min b. Abdilhak el-Bağdâdî, Kavâ'idu'l-usûl ve me'âkidu'l-fusûl muhtasaru tahkîki'emeli fi 'ilmeyi'l-usûli ve'l-cedel, thk. Enes b. Âdil ve Abdülaziz b. Adnân (Kuveyt: Dâru'r-Rekâiz, 1439/2018), 68 . 
sunda mesnetsiz şahsî yorumlar ortaya çıkar. Bu türden yorumların kişiyi, Kur'ân'ın ana maksatlarıyla çelişen istikamete sürükleyeceği aşikârdır. Bunun tefsir tarihinde pek çok örneği olduğu gibi hala aynı riskin devam ettiği müşahede edilmektedir.

Müşkil âyetlerin bahsi geçen farklı anlamlandırılma kapasitesine ve bu türe giren âyetlerin hangi yöntemle anlamlandırılması gerektiğine örnek olması için Hz. Meryem'in annesinin başından geçenleri tasvir eden Âl-i İmrân sûresi 36. âyetini inceleyeceğiz. Hz. Meryem'in annesi Hanne yaşlı ve kısır olduğu halde bir çocuğa hamile kalmıştır. Sıra dışı olan bu hamileliğin ilahi bir lütuf olduğunu düşünen kadın doğacak çocuğunu Yahudi mabedine adak olarak vermeyi ahdetmiştir. Ne var ki çocuk mabette hizmet edebilecek bir erkek değil kız olarak dünyaya gelmiştir. Âyet şu şekildedir:

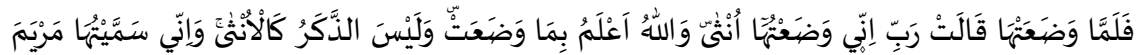

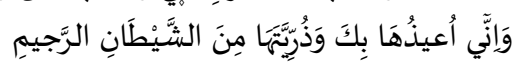

"Onu doğurunca dedi ki: "Rabbim! Onu kı doğurdum, -Oysa Allah onun ne doğurduğunu daha iyi bilmektedir- erkek de kız gibi değildir. Ben onun adını Meryem koydum, işte ben onu ve soyunu kovulmuş şeytana karşı senin korumana bırakıyorum."

İște bu âyetin manası, -yukarıda bahsini yaptığımız müşkil âyetlerde olduğu gibipek çok açıdan farklı şekilde yorumlanmaya müsaittir. Biz bu çalışmada özellikle

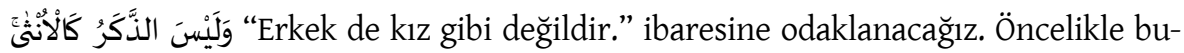
rada farklı yorumlara neden olan ihtilafların neler olduğunu başlıklar halinde vermek faydalı olacaktır.

a) Bu ibâre Allah'a mı yoksa Hz. Meryem'in annesine mi aittir?

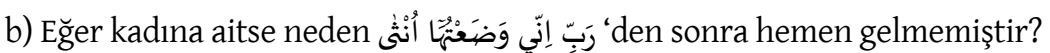

c) Bu ibarede erkek ve kız arasında bir üstünlük kastı var mıdır?

d) Eğer varsa üstün tutulan kız mıdır yoksa erkek midir?

e) Erkek ve kız kelimeleri arasında bir takdim-tehir söz konusu mudur?

Burada ilgili sorular çerçevesinde ibare hakkında yapılan en isabetli görüşün izi klasik tefsirlerde sürülecektir. Fakat daha önce de belirttiğimiz gibi âyet, müşkil kapsamında olduğu için birden fazla sahih anlama müsait olabilir. Bu manaların her biri siyak ve dilbilimi açısından kendi deliline göre tutarlı olabilir. O yüzden burada müfessirlerin verdikleri anlamlar kendi gerekçeleri ile birlikte ele alınarak değerlendirilecektir.

\section{1. İbârenin Kime Ait Olduğu Hakkında Söylenenler}

Her şeyden önce ifadenin kime ait olduğuna dair tefsirciler arasındaki ihtilafa değinmek gerekmektedir. Taberî (öl. 310/923) tefsirinde ilgili ibare hakkında tek bir görüş serdetmiştir. 0 da erkeğin mabedin hizmetlerini görme hususunda daha muktedir olduğudur. Zira kız bazı hallerde mabede giremeyecek ve oraya ait bazı vazifeleri hakkıyla icra edemeyecektir. Hayız ve nifas gibi manilerden dolayı erkeğin yerini tutamayacaktır. Anlaşılan Taberî, ibarenin Hanne'ye ait olduğu düşüncesinde Katâde (öl. 117/735) ve İkrime'nin (öl. 105/723) görüşlerini benimsemiştir. Onlara göre kız, malum hallerinden dolayı mabetteki vazifeleri yapamayacaktır. Bu yüzden Han- 
ne'den "erkek kız gibi değildir." şeklinde bir hayıflanma hali sadır olmuştur. ${ }^{9}$ Taberînin tâbiûn döneminden iki büyük müfessir isme dayandırdığı bu kaviller, yüzyıllar boyu pek çok tefsir kaynağında ilgili ibarenin yorumunda etki edecektir.

İbn Ebî Hâtim'in (öl. 327/938) naklettiğine göre Hanne karnındaki çocuğun erkek olacağını düşünerek onu ibadete adamıştır. Bu işi yerine getirmek için erkek kızdan daha أقوى muktedirdir..$^{10}$ Mâturîlî’nin (öl. 333/944) aktardığına göre ilgili ibare Hz. Meryem'in annesine aittir. Bu kavle göre Hanne, hıfz, taâhüd ve bunlara ait vesilelerin sağlanması hususunda erkeğin ihtiyaç duymadığı şeylere ihtiyaç duyar. ${ }^{11}$ Ebu'lLeys es-Semerkandînin (öl. 373/983) yer verdiği görüşlerden birisine göre bu kelâmın muhatabı Hz. Peygamber'in kendisidir. Müfessirin Katâde'den aktardığına göre bu âyette bir takdim söz konusudur. Bu takdire göre Hanne şöyle demiştir: "Rabbim ben kız doğurdum. Erkek kız gibi değil. Allah onun ne doğurduğunu en iyi bilendir." Bu yoruma göre "Allah onun ne doğurduğunu en iyi bilendir." ibaresinin yeri tehir edilmiştir. $^{12}$

Mekkî b. Ebû Talib de (öl. 437/1045) burada takdim ve ibarenin Hanne'ye ait olduğunu ifade etmiştir. ${ }^{13}$ Mâverdîye (öl. 450/1058) göre ibadet için tahsis edilen böyle bir mekânda hizmet, erkeklere mahsus olduğu için Hanne öyle demiştir. ${ }^{14}$ Vâhidîye (öl. 468/1076) göre ise kız hayız ve nifas gibi kadına arız olan hallerden dolayı adandığı mabedin hizmetini görme hususunda erkek gibi değildir. ${ }^{15}$ Semânîye (öl. 489/1096) göre bu ibare Hanne'ye aittir. Anne çocuğun kız oluşundan müteessir olduğu için de Allah "Allah onun en doğurduğunu en iyi bilendir" demiştir. ${ }^{16}$ Râgıb el-ìsfehânî de (öl. 502/1108) Hanne'nın, kız çocuğunu kavrayış ve dini yaşantı bakımından nakıs gördügü için tahassürünü o şekilde ifade ettiğini belirtmiştir. ${ }^{17}$ Ebû Muhammed el-Beğavî (öl. 516/1122) de ilgili ibarede kızın erkek gibi mabede ait hizmetleri kadınlı̆ga ait özel hallerden dolayı icra edemeyeceği için bu sözü söylediğini ifade etmiştir. ${ }^{18}$

9 Ebû Ca'fer Muhammed b. Cerîr b. Yezîd el-Âmülî et-Taberi, Câmiu'l-beyân, thk. Ahmed Muhammed şâkir (Beyrut: Muessesetu'r-Risâle, 2000), 6/335-336.

10 Ebû Muhammed Abdurrahmân b. Muhammed b. İdrîs er-Râzî, Tefsîrü'l-Kur'âni'l-'azîm, thk. Es'ad Muhammed et-Tayyib (Arabistan: Mektebetu Nizâr Mustafâ el-Bâz, 1419), 2/537

11 Ebû Mansûr Muhammed b. Muhammed b. Mahmûd el-Mâtûrîdî, Te'vîlâtu Ehli's-Sunne, thk. Mecdî Beslûm (Beyrut: Dâru'l-Kutubi'l-ilmiyye, 2005), 2/358.

12 Ebü'l-Leys İmâmü'l-hüdâ Nasr b. Muhammed b. Ahmed b. İbrâhîm es-Semerkandî, Bahru'l-ulûm, thk. Ali Muhammed Mu'avvad, Adil Ahmed Abdülmevcûd ve Zekeriyyâ Abdülmecîd en-Nûtî (Beyrut: Dâru'lKütübi'l-'ílmiyye, 1413/1993), 1/263.

13 Ebû Tâlib Muhammed b. Alî b. Atıyye el-Mekkî el-Acemî, el-Hidâye ilâ bulûğinn-nihâye, thk. Heyet (Şârika: mecmûmatu Buhûsi'l-Kitâbi ve's-Sunne, 2008), 2/995

14 Ebü'l-Hasen Alî b. Muhammed b. Habîb el-Basrî el-Mâverdî, en-Nüketu ve'l-uyûn, thk. Seyyid Abdülmaksûd b. Abdurrahîm (Beyrut: Dâru'l-Kutubi'l-İlmiyye, ty.), 1/387.

15 Ebü'l-Hasen Alî b. Ahmed b. Muhammed en-Nîsâbûrî el-Vâhidî, el-Vecîz fì tefsîri'l-kitâbi'l-'azîz, thk. Safvân Adnân Dâvûdî (Şam: Dâru'ş-Şâmiyye, 1415), 208

16 Ebü'l-Muzaffer Mansûr b. Muhammed b. Abdilcebbâr et-Temîmî el-Mervezî es-Sem ânî, Tefsiru'l-Kur'ân, thk. Yasir b. İbrâhîm (Riyâd: Dâru'l-Vatan, 1997), 1/312

17 Ebü'l-Kāsım Hüseyn b. Muhammed b. el-Mufaddal er-Râgib el-İsfahânî, Tefsîru'r- Râgıb el-i̇sfâhânî, thk. Âdil b. Alî (Riyâd: Dâru'l-Vatan, 2003), 2/528.

18 Ebû Muhammed Muhyissünne el-Hüseyn b. Mes'ûd b. Muhammed el-Ferrâ' el-Begavî, Me'âlimü't-tenzîl, thk. Osmân Cuma (Beyrut: Dâru İhyâi't-Turâsi'l-Arabi, 1997), 2/30. 
Zemahşerî (öl. 538/1144) ilgili ifadenin, kendinden önceki وَالسَّ أَعْلَمُ بِما وَضَعَتُ “Allah ne doğurduğunu daha iyi bilendir." âyetine beyan/açıklama olduğunu ifade etmiştir. $\mathrm{Bu}$ beyandan maksat ise mevzuyu tazim ve yüceltmedir. Buna göre şöyle bir anlam hâsıl olmaktadır: Senin talep ettiğin o erkek Allah'in sana verdiği bu kız gibi değildir. Bu tefsirde zeker/erkek ve unsâ/kız ifadelerindeki elif lam takısı ahd manasındadır. ${ }^{19}$ Görüldüğü kadarıyla Zemahşerîye kadar, ilgili ibareye verilen anlamın tayininde Katâde ve İkrime'nin görüşlerinin ağırlığı açık bir şekilde hissedilmektedir. Zemahşerî ise bu görüşü kayda değer görmemiş ve nahiv verilerini kullanarak kendisine kadar söylenenlerden farklı hatta tam tersi bir anlamı ibareye yüklemiştir. Zemahşerî'den sonra onun görüşünün tefsirlerde ve ulûmu'l-Kur'ân kaynaklarında ${ }^{20}$ kabul gördüğü hatta bazılarında en isabetli görüş olarak tercih edildiği görülecektir. Nitekim hiçbir lafız değişikliği olmadan aynı yorum Beydâvî'de de (öl. 685/1286) görülür. Fakat Beydâvî, ilgili ibarenin Hanne'ye ait olmasını da mümkün görür. Bu takdirde iki kelimedeki elif lam takıları cins anlamı ifade eder. Buna göre anlam 'adadığım şeyde erkek ve kız aynı değiller' anlamına gelir. ${ }^{21}$

Bu konuda en kapsaml yorumları Fahreddîn er-Râzînin (öl. 606/1210) bir araya getirdiği görülmektedir. Râzî burada ilgili ibarenin Hanne'ye ait olduğunu kabul etmekte ve ayeti bunun üzerinden iki farklı şekilde yorumlamaktadır. Bunlardan ilkine göre Hanne'nin “Erkek kız gibi değildir" sözünü söylemesinin maksadı erkeğin kızdan adanma konusunda üstünlüğünü ortaya koymaktır. Bu efdaliyetin gerekçeleri vardır. Mabedin hizmetinde bulunma hususunda erkek olmanın ontolojik üstünlükleri bulunur. Erkek hayız, nifas gibi mabette bulunmaya mâni olan engellerden halidir ve mabedin hizmetini görmek için gerekli fiziki güce sahiptir. Mabede devam eden erkeklerle ihtilat etme mecburiyeti olacağı için bu içli dışlı oluşa kadınlık manidir. Erkeğin diğger erkek cemaat ile bir arada bulunmasında herhangi bir sakınca yokken kadın hakkında ise durum öyle değildir. Bütün bunlar ilgili ibareye mabede adanma hususunda "erkeğin kadına üstünlügü̆" şeklinde bir anlam vermek için makul argümanlardır. Diğer görüşe göre Hanne kendisine bahşedilen kızı erkeğe üstün tutmuştur. Zemahşer̂̂nin dile getirdiği yorum burada karşımıza çıkmaktadır. Tekrar edecek olunursa bu yoruma göre Hz. Meryem'in annesi şöyle demiştir: "istediğim erkekti. Fakat bu kız ise Allah’ın bana bahşettiği bir ihsan. İstediğim olan erkek, Allah'ın bana bahşettiği kız gibi değildir.” Böyle bir yoruma göre Meryem'in annesi, Allah'ın kendisine verdiği şeyin kendisi için istediği şeyden daha hayırlı olduğunu bilen, Allah'ın marifetine müstağrak olmuş bir kadındır. ${ }^{22}$ Râzî, bu iki görüş arasında açıkça bir tercihte bulunmamıştır. İki görüşün kendilerini destekleyen gerekçelerini zikretmiştir.

19 Ebü'l-Kāsım Mahmûd b. Ömer b. Muhammed el-Hârizmî ez-Zemahşerî, el-Keş̧̧âf 'an hakạāikịı ġavâmizii'ttenzîl ve 'uyûni'l-ekāvîl fi vücûhi't-te'vîl (Beyrut: Dâru'l-Kutubi'l-Arabî, 1407), 1/356.

20 Ebû Abdillâh Bedrüddîn Muhammed b. Bahâdır b. Abdillâh et-Türkî el-Mırrî el-Minhâcî ez-Zerkeşî, el-Burhân fí 'ulûmi'-Kur'ân, thk. Muhammed Ebu'l-Fadl ỉbrâhîm (Beyrut: Dâru i̇hyâi'l-Kutubi'l-Arabiyye, 1967), 4/88.

${ }^{21}$ Nâsırüddîn Ebû Saîd (Ebû Muhammed) Abdullāh b. Ömer b. Muhammed el-Beyzâvî, Envâru't-tenzîl ve esrâru't-te'vîl, thk. Muhammed Abdurrahman (Beyrut: Dâru İhyâi't-Turâsi'l-Arabî, 14189, 2/14.

22 Ebû Abdillâh (Ebü'l-Fazl) Fahrüddîn Muhammed b. Ömer b. Hüseyn er-Râzî et-Taberistânî, Mefâtihu'lgayb (Beyrut: Dâru İhyâi't-Turâsi'l-Arabî, 1420), 8/204. 
Nizâmuddîn en-Nîsâbûrîye (öl. 730/1329) göre buradaki cümlelerin tamamen Hanne'ye ait olması ihtimal dâhilindedir. Bu yoruma göre kadın, Râzînin dediği gibi Allah'ı tanıyan ve O'ndan gelen her şeyde bir hayır olduğuna tam güvenen birisidir. Adadığı erkek çocuk yerine kızı olduğunu görünce Hanne "Allahım! Kız doğurdum. Fakat sen doğuran kişinin halini en iyi bilensin. Umarım ki bunda senin bir sırrın vardır. Senden talep ettiğim erkek senin bana bağışladığın bu kız gibi değildir. Zira sen ne yaparsan onda bir hikmet ve maslahat vardır." demiştir. Müfessir yer verdiği bu görüşü "el" takısı ile gerekçelendirmektedir. Zeker kelimesindeki el takısı annenin zihninde ma'hûd olan bir erkeğe zımnen, unsâ kelimesindeki $e l$ ise daha önce zikri geçtiği için kıza hakiki olarak delalet etmektedir. ${ }^{23}$

İbn Kesîr (öl. 744/1373) ibareden önce gelen وَضَ ifadesinin te harfinin ref üzere olup "ben doğurdum" şeklindeki kıraatine atıfta bulunmuş ve bu takdirde cümlenin Hanne'ye ait olduğunu söylemiştir. Aksi takdirde kelam Allah'a ait olacaktır. وََلَيَسنَ الذَّكَرُ كَالْنُثْثى ibaresi için de ibadet ve Mescid-i Aksa'ya hizmette kuvvet ve sebat hususunda erkek kız gibi değildir şeklinde tefsirde bulunmuştur. ${ }^{24}$

Ebû Hayyân el-Endelûsî ise (öl. 745/1344) ayrıntılı bir şekilde ibare hakkında bilgiler vermiștir. Önce ibare hakkında Katâde, İkrime gibi tabiûn müfessirlere ait kavle yer verir. Bu kavle göre daha önce bahsedildiği gibi Hanne, mabede adadığı çocuğun erkek olmasını arzulamıştır. Zira bu vazife için uygun olan çocuk erkek olmadır. Bu

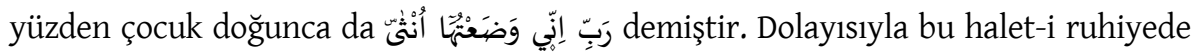

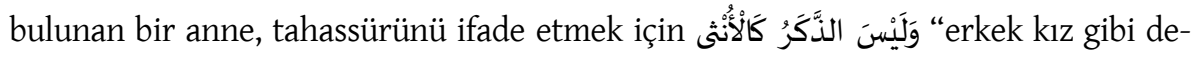
ğildir." ifadesini kullanmıştır.

Bunlar Ebû Hayyân'ın yer verdiği bir görüştür ki bu görüş hemen hemen tüm tefsirlerde tekerrür etmiştir. Daha sonra müfessir kendi görüşünü belirtir. Buna göre

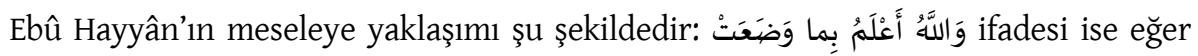

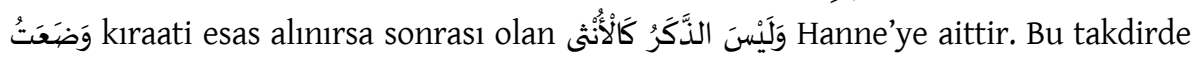
sanki Hanne kendine dönerek erkek çocuğu olmadığı için nefsini teselli etmek üzere "Allah daha iyi bilir." demiştir. Allah'ın ilmi, kudret ve hikmeti (bunlara olan iman), elde edilemeyen bir maksattan dolayı (erkek çocuk) tahassür gösterilmemesine sevk etmektedir. Zira Allah'ın muradı, kulunun da irade ettiği bir murâd olmalıdır. Bundan dolayı istediğim ve ümit ettiğim erkek çocuk, Allah'ın ilminde, onun murâd buyurduğu ve karar verdiği bu kız gibi değildir. Umulur ki bu kız erkekten daha hayırlı olur. Zira bu kızı Allah murâd ettiği için elbette ki daha hayırlıdır. Hanne kendisini bu şekilde teselli etmiştir.

الذَّكرُ kelimesindeki el takısı ahd manasına gelir. Bu takdirde anlam; Allah'in bahşettiği bu kız erkek olmasını umduğun çocuktan üstündür şeklinde olur. Buna karşıllk anlam tam tersi de olabilir. Buna göre de anlam; Mescid-i Aksa'ya adanması ümit

${ }^{23}$ Nizâmüddîn Hasen b. Muhammed b. Hüseyn el-A'rec en-Nîsâbûrî, Garâibu'l-Kur'ân, thk. Zekeriyyâ Umeyrât (Beyrut: Dâru'l-Kutubi'l-i̇lmiyye, 1416), 2/149.

24 Ebü'l-Fidâ' İmâdüddîn İsmâîl b. Şihâbiddîn Ömer b. Kesîr b. Dav' b. Kesîr, Tefsîru İbn Kesîr, thk. Muhammed Huseyn Şemsuddîn (Beyrut: Dâru'l-Kutubi'l-İlmiyye, 1419), 2/28. 
edilen erkek çocuk, yukarıda zikredilen malum sebeplerden dolayı kız gibi değildir. Ebû Hayyân daha sonra İbn Atiyye, Katâde, Rabi‘, Süddî ve İkrime'nin erkek çocuğunun malum hizmete daha uygun olacağı yönündeki görüşlerine yer vermiştir.

Yaptığı nahvi tevcihleriyle ilgili ibarenin anlaşılmasında dönüm noktası olarak kabul edebileceğimiz Zemehşerîyye bir itiraz Ebû Hayyân'dan gelmektedir. Zemahşerî, yukarıda zikri geçtiği gibi Hanne'nin “Kız doğurdum” sözünden sonra gelen وَاللهُ "Erkek "Erkek klz gibi değildir." cümlelerini itiraziyye olarak kabul etmiştir. Ebû Hayyân buna itiraz eder.

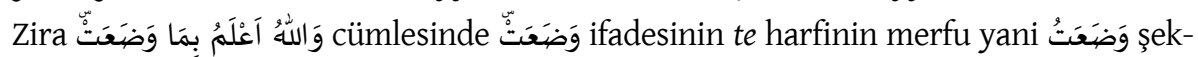
linde kıraat edildiği bir kıraat vardır. ${ }^{25}$ Bu kıraate göre siyak; Rabbim kız doğurdum. Allah benim ne doğurduğumu en iyi bilendir. Erkek kız gibi değildir. Bu takdirde itiraziyye

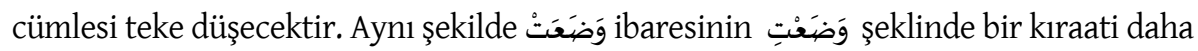

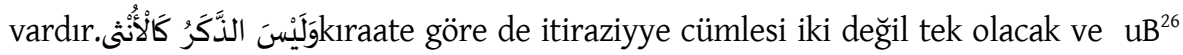
ifadesi Meryem'in annesine ait olacaktır. Diğer taraftan itiraziyye cümlesinin iki tane olması hususunda ihtilaf vardır. Ebû Alî’ye göre iki cümle itiraziyye olamaz. Hakikaten de Zemahşerî̀ye baktığımızda, ilgili ibareye anlam verirken bu kıraat farklılıklarına değinmediği ve meseleyi sadece tek bir kıraati ve itiraziyye cümlelerini iki tane gelebileceği şeklindeki tek bir yorumu esas alarak halletmeye meylettiği anlaşılmaktadır. Bunlar Ebû Hayyân'ın Zemahşerînnin yaklaşımına yönelttiği tenkitlerdir. ${ }^{27}$

İbarenin kime ait olduğunun mana üzerinde etkili olduğu hususu müfessirlerin yaklaşımından anlaşılmaktadır. Örneğin müteahhirun müfessirlerden İbn Acîbe (öl. 1224/1809) söz konusu ibarenin Allah'a yahut Hz. Meryem'in annesine ait olmas1 durumuna göre iki yoruma da yer vermiş ve aralarında bir tercihte bulunmamıştır. İbn Acîbe وَالسَُّ أَعْلَمُ بِما وَضَحَتَتْ ibaresi hakkında da iki ihtimali göz önünde bulundurmuştur. Bu ibare Allah'a ait ise maksat doğan çocuğun Allah indindeki ehemmiyetini vurgulamak içindir. Şayet ibare وضُعْ şeklinde kıraat edilirse anneye aittir. Bu takdirde anne kendi kendisini teselli etmektedir. "Belki bir sır vardır." diyerek gönlündeki tahassürü teskin etmeye çalışmaktadır. ${ }^{28}$

\section{2. Âyet İçerisinde Takdim-Tehir Olduğu Düşüncesi}

İbnü'l-Cevzî (öl. 597/1201), âyet içerisinde daha önce de bahsedildiği gibi takdim olgusunun varlığından bahsederek meseleyi kıraat farklılıklarıyla izah etmeye çalışır. İbn Âmir, Âsım (Hafs dişında) ve Ya'kûb kıraatlerine göre أَعْلَمُ بِمَا وَضَعَتَ iffadesindeki

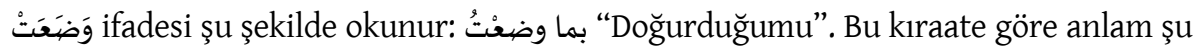

${ }^{25}$ Muhammed b. Kâsim Ebû Bekr İbnü'l-Enbârî, Îdâhu'l-vakfi ve'l-ibtidâ, thk. Muhyiddîn Abdurrahmân Ramadân (Şam: Matbaatu Mecmau'l-Lugati'l-Arabiyye, 1971), 2/575.

${ }^{26}$ Ahmed b. Abdülkerîm el-Eşmûnî, Menâru'l-Hüdâ fi beyâni'l-vakfi ve'l-ibtidâ, thk. Şerîf Ebu'l-Alâ (Beyrut: Dâru'l-Kutubi'l-İlmiyye, 2002), 165.

27 Ebû Hayyân Muhammed b. Yûsuf b. Alî b. Yûsuf b. Hayyân el-Endelüsî, el-Bahrü'l-muhịt, thk. Sttkî Muhammed Cemîl (Beyrut: Dâru'l-Fikr, 1420), 3/117-118.

28 Ebü'l-Abbâs Ahmed b. Muhammed b. Mehdî el-Hasenî eş-Şâzelî ìbn Acîbe, el-Bahrü'l-medîd fi tefsîri'lKur'âni'l-mecîd, thk. Ahmed Abdullah el-Kureşî (Beyrut: Dâru'l-Kutubi'l-İlmiyye, 2002), 1/346. 
şekilde olur: "Rabbim kız doğurdum. Allah benim ne doğurduğumu daha iyi bilendir." Böyle bir kıraattan sonra gelen "Erkek kız gibi değildir." ibaresi hakkında herhangi bir tehir söz konusu olmaz. Ancak müfessirin İbn Kuteybe'den (öl. 276/889) aktardığına göre ilgili ibare tahkik üzere وَضَ şeklinde okunursa burada takdim-tehir olacaktır. ${ }^{29}$ وضعَ şeklindeki okuyuşa göre ise takdim söz konusu değildir. İlgili ibare Hz. Meryem'in annesine ait olacaktır. ${ }^{30}$

Hâzin (öl. 741/1341) ilgili ibare hakkında bir takdim-tehirin söz konusu olduğu görüşünü aktarmıştır. Ona göre takdir şu şekildedir: وليس الأنثى كالذكر "Kız erkek gibi değildir.” Yani kız erkeğin yerini tutamaz. Hâzin'in görüşüne göre cümlelerin akışında anne, kız çocuğu doğurduğundan dolayı üzülmektedir. Dolayısıyla "Erkek kız gibi değildir." şeklindeki ibarenin belagat açısından kızın erkekten üstün tutulduğuna delalet ettiğini düşündüğ̈̈ için de ibarede takdim-tehir edildiğini söylemektedir. Bu görüşü Hâzin kendisine nispet etmektedir. İkinci bir görüş olarak da kızın üstün tutulduğuna dair bahsedilen görüşlere yer vermiştir. ${ }^{31}$

Semîn el-Halebî (öl. 756/1355) ise ibare hakkında nispeten daha dakik bir tahlile girmiştir. Buradaki yorumlar Zemahşerî tarafından söylenmiş şeyler olduğu için tekrar etmeye gerek yoktur. Fakat burada müellife ait özgün ve farklı bir yorum olarak şunu görüyoruz: Âyetin siyakına göre ليس "değildir.” olumsuzluk ifadesi, annenin zihninde karar bulmuş "erkeğin üstünlüğü" yargısına yöneliktir. Zihinde erkek olacağ tasavvur edilerek mabede adanan erkek çocuğun farazi kemalini nefyetmek için böyle bir cümle kurulmuştur. Asıl itibariyle cümle kuruluşu "Kız erkek gibi değildir." şeklinde iken takdim yapılarak "Erkek kız gibi değildir." denilmiştir. Müfessire göre bu takdim tehirin nedeni kadının dikkatinin erkek çocuğa yönelik olmasındandır. Kadın tüm dikkatiyle erkek çocuğuna odaklandığı ve gönlünde hüküm süren erkek cinsiyeti olduğu için zeker takdim edilmiştir. Bu takdire göre anlam şu şekildedir: Aralarındaki farklılıktan dolayı erkek cinsi kız cinsi gibi değildir. Eğer âlimlerin istihraç ettiği bu anlamlar olmasaydı leyse ile kurulan cümlenin bir anlamı kalmayacaktı. Zira malum olduğu üzere erkek kız gibi değildir. Âyet, zaten herkesçe malum ve bedihi olan iki cins arasındaki farkı haber vermek gibi bir maksada matuf olmamalıdır. ${ }^{32}$

Ebû Zeyd es-Seâlibî (öl. 875/1471) ise ilgili ibarenin kadına ait olduğu düşüncesine sahiptir. Zira kadın demiş ve kız çocuğu doğurduğu için üzülmüştür. Dolayısıyla erkek kız gibi değildir cümlesi de ona ait olmalıdır. Buna göre kadın çocuğun kı olduğundan dolayı malum sebeplerden dolayı mabette hizmet edemeyeceğini düşünerek bu sözü söylemiştir. Seâlibî bu görüşünü Katâde'ye dayandırmak-

29 Ebû Muhammed Abdullāh b. Müslim b. Kuteybe ed-Dîneverî, Garîbi'-Kur'ân, thk. Ahmed Sakr (Beyrut: Dâru'l-Kutubi'l-ilmiyye, ts.), 104

30 Ebü'l-Ferec Cemâlüddîn Abdurrahmân b. Alî b. Muhammed el-Bağdâdî, Zâdu'l-Mesîr, thk. Abdürrezzâk el-Mehdî (Beyrut: Dâru'l-Kitâbi'l-Arabî, 1422), 1/276

31 Ebü'l-Hasen Alâüddîn Alî b. Muhammed b. İbrâhîm el-Hâzin el-Bağdâdî, Lübâbü't-te'vîl fì me âni't-tenzîl (Beyrut: Dâru'l-Kutubi'l-illmiyye, 1415), 1/240.

32 Ebü'l-Abbâs Şihâbüddîn Ahmed b. Yûsuf b. İbrâhîm (Abdiddâim) el-Halebî, ed-Düreru'l-masûn, thk. Ahmed Muhammed el-Harrâd (Şam: Dâru'l-Kalem, ts.), 3/137. 
tadır. Seâlibî burada "Erkek kız gibi değildir." ibaresinde erkeğin önce kızın sonra zikredilmesinde bağlama yüklediği anlama ters düşen bir şeyler olduğunu hissetmiştir. Zira erkeğin kız gibi olamayacağı ifadesinde kızın üstün tutulduğuna dair bir karine vardır. Hâlbuki kız erkek gibi değildir denilseydi bağlama daha uygun düşerdi. Seâlibî bundan dolayı ilgili ifade de bir takdimin olduğunu düşünmüştür. Ona göre takdir şu şekildedir: Kız erkek gibi değildir. Bu takdimin nedeni ise kadının zihninin erkek çocuğu ile meşgul olmasından dolayıdır. Zihni erkek çocuğuna takılmış ve kız çocuğu olduğunu görünce erkek cinsini önce zikrederek erkeğin üstünlüğünü kastederek “Erkek kız gibi değildir.” demiştir. ${ }^{33}$

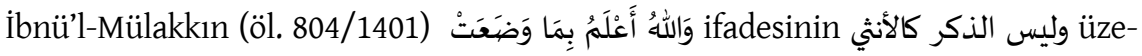
rine takdim edildiğini belirtmiştir. Zira İbnü'l-Mülakkın, İbn Abbas'ın sadece erkek çocuklarının adak olarak Mescid-i Aksa'ya kabul edildiği kavline yer vermiştir. 0 halde İbn Abbâs kavline göre Hanna erkek doğurmadığı için üzülmüş, "ama erkek kız gibi değil" diyerek erkek çocuk beklentisini dile getirmek istemiştir. Fakat bu ifade tehir edilmiştir. ${ }^{34}$

Süyûti de (öl. 911/1505) وَلَيَنْ الذَّكَرُ كَالأُنْنَىَ ifadesinde takdim olduğunu düşünmektedir. Önce kızın zikredilmesi gerekirken erkek takdim edilmiştir. Süyûtî’ye göre

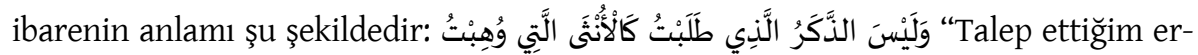
kek bana bahşedilen kız gibi değildir.” Bu takdim-tehirden maksat bir kavle göre fasıla uyumu içindir. Zira إِّنِي وَضَعْتُهَا أُنْنَى ibaresindeki fasıla harfi olan elif-i maksureye uyumlu olması için burada da كَالََُّْْْ tehir edilmiştir. ${ }^{35}$

Muasır dil âlimlerinden Abdülazîm el-Mat'anî de (öl. 2008) yukarıda bahsedilen takdimdeki sırrın Hanna'nın gönlünü tamamen erkek çocuk isteği kaplamış olabileceğine bağlamaktadır. ${ }^{36}$

\section{Yakın Dönem Müfessirlerinin Yorumları}

Şevkânî (öl. 1250/1834) ise ibarenin Hz. Meryem'in annesine ait olup manasının da erkeğin üstünlügüne delalet ettiğine dair kavillerden önce şahsi görüşüne yer vermiştir. Ona göre “Erkek kız gibi değildir.” ibaresi, “Allah'ın onun neyi doğurduğunu daha iyi bildiği” hükmüyle vurgulanan meselenin büyüklüğüne dair varîd olmuş bir itiraziyye cümlesidir. Çocuğun erkek olmasından annenin murad ettiği en yüksek gaye, onun mabede adanmış bir hizmetkâr olması idi. Hâlbuki dünyaya gelen bu kızın mânevî mertebesi çok yüksektir; ehemmiyetli bir mertebeye sahiptir. Bu manaya göre zeker ve unsâ kelimelerindeki lam harfleri ahd ifade eder. Şevkânî sabık tefsirlerde geçen İbn Âmir kıraatine yer vererek bu durumda ibarenin annenin üzün-

33 Ebû Zeyd Abdurrahmân b. Muhammed b. Mahlûf es-Seâlibî, el-Cevâhirü'l-hịsân fi tefsî̀r'l-Ḳur'ân, thk. Şeyh Muhammed Alî (Beyrut: Dâru İhyâi't-Turâsi'l-Arabî, 1418), 2/34.

34 Ebû Hafs Sirâcüddîn Ömer b. Alî b. Ahmed el-Ensârî el-Mısrî İbnü'l-Mulakkın, Şevâhidü't-tavziih fị şerhịilCâmi'i'ș-șahîh (Şam: Dâru'n-Nevâdir, 2008), 19/539.

35 Ebü'l-Fazl Celâlüddîn Abdurrahmân b. Ebî Bekr b. Muhammed el-Hudayrî es-Süyûtî, el-itkân fí ulûmi'lKur'ân, thk. Muhammed Ebu'l-Fadl i̇brâhîm (Mısır: el-Hey'etu'l-Mısriyye, 1974), 3/147.

36 Abdülazîm İbrâhîm el-Mat'anî, Hasâisu't-ta'bîri'l-Kur'ânî (Mısır: Mektebetu Vehbe, 1992), 2/279. 
tüsüne işaret ettiği görüşüne yer vermiştir. Fakat burada Şevkânînin ilk görüşü esas aldı̆̆ı açıcça görülmektedir. ${ }^{37}$

Reşid Rizâ’ya (öl. 1935) göre وَاللَهُ أَعْلَمُ بِمَا وَضَعَتَ cümlesi ile doğurduğu kızın yüksek mertebesi ifade edilmektedir. Böyle bir kız birçok erkekten daha hayırlıdır. Bu ifade ile annenin sözlerinde kız çocuğuna karşı bir tiksinti duyduğu ve erkek karşısında kızın daha düşük mertebede olduğu şeklindeki bir vehim ortadan kaldırılmıștır. Bu vehmin ortadan kaldırıldığını ise bir sonraki ibare وليس الأنثى كالذكر"K1z erkek gibi değildir." ifade etmiştir. Reşid Rızâ da وضُعْتُ kıraatılla anlamın nasıl değiştiğine dair mezkûr anlam değişikliğine kısaca yer vermiştir. Fakat onun da meylettiği görüşün bu olmadığı anlaşılmaktadır. ${ }^{38}$

Muasır müfessirlerden Mısırlı Şa'râvî (öl. 1998) ilgili ibarenin kime ait olduğu ile ilgili iki ihtimalin de mümkün olduğunu, dileyenin dilediği gibi tercih edebileceğini belirtir. Zira dil bu iki ihtimale imkân vermektedir. Fakat o bu sözün Allah'a ait olduğu ve manasının da doğan kız çocuğunun harikulade bir meziyete sahip olduğu ve dolayısıyla da böyle bir meziyete zihninde tasavvur ettiği erkeğin ulaşamayacağını ifade etmiştir. Müfessir doğan kı çocuğunun, mabedin hizmetine girecek ve ömrünü dini bir mekânın ihtiyaçlarına sarf edecek bir erkekten hangi açılardan daha üstün olduğuna dair kendi düşüncelerini paylaşmıştır. Buna göre Hz. Meryem'in üstünlügü her şeyden önce çok büyük bir kudret mucizesi ile dünyaya gelecek Hz. İsâ’yı doğuracak olmasıdır. ${ }^{39}$

Mısırlı Müfessir Abdülkerîm el-Hatîb (öl. 1985) ilgili ibarenin Allah'a ait olduğuna ve maksadın dünyaya gelen kız çocuğu Meryem'in üstünlügüne delalet ettiğine dair en uzun yorum yapan müfessirlerden biridir. Onun yorumuna göre İmran'ın eşinin temenni ve ümit ettiği erkek, Hz. İsâ’yı doğuracak olan Hz. Meryem gibi değildir. Eğer İmrân'ın eşi erkek çocuk doğursaydı İsa (a.s.) gibi kadri büyük bir insanın doğumuna vesile olamazdı. Bu manadan dolayı "Erkek kız gibi değildir." teşbih üslubu çok ilginç bir şekilde gelmiştir. Müfessir, ibarenin kime ait olduğu ve kı-erkek arasında bir karşılaştırma ile maksadın neler olabileceğine dair tefsirciler arasında yaşanan ihtilafın varlığından haberdardır. Fakat ona göre aslında sadece buradaki teşbihe dikkat etmek âyetin maksudunu anlamak için yeterlidir. Bu teşbihe göre kadın ve erkek arasında mutlak bir üstünlük kastedilmiş değildir. Sadece, annenin zihninde tasarladığı erkek çocuğunun, dünyaya gelen ve ileride büyük bir işle memur kılınacak olan Hz. İsâ'nın annesi olacak Hz. Meryem seviyesine çıkamayacağı manası murattır. ${ }^{40}$

Muasır müfessirlerden Muhammed el-Mekkî en-Nâsırî (öl. 1994) ise ilgili ibareyi anneye nispet etmiştir. İbarenin anneye ait olduğuna kail olan müfessirler daha önce görüldüğü gibi annenin üzüntüsünden dolayı böyle söylediğini belirtmişlerdir. Mekkî de ifadenin kadına ait olmasından kaynaklanan erkek üstünlüğü manasını

37 Ebû Abdillâh Muhammed b. Alî b. Muhammed eş-Şevkânî, Fethu'l-Kadîr (Şam: Dâru İbn Kesîr, 1414), $1 / 384$.

38 Reşid Rızâ, Tefsîru'l-menâr (Mısır: el-Heyetu'l- Mısriyyetu'l-Âmme, 1990), 3/238.

39 Muhammed Mütevellî Şa'râvî, Tefsîru'ş-şa'râvî (Mısır: Ahbâru'l-Yevm, 1991), 1436.

${ }^{40}$ Abdülkerîm el-Hatîb, et-Tefsîru'l-Kur'ânî li'l-Kur'ân (Kahire: Dâru'l-Fikri'l-Arabî, ts.), 2/436. 
münasip bulmamış olacak ki âyetin bağlamında kadının değerinin düşürüldüğü gibi bir anlamın bulunmadı̆̆ını ifade etmiştir. Bilakis âyetin siyak/bağlamına bakıldı̆̆ına tam tersine Meryem ve annesi şahsında kadının onurlandırıldığını söylemektedir. Müfessire göre ilgili ibareden maksat kadın ve erkek arasında yaratılıştan gelen bir farklılığın beyan edilmesidir. Erkeğin yaptı̆̆ı bazı şeyleri tam olarak kadın yapamaz kadının muvaffak olduğu bazı şeyleri de erkeğin mükemmel olarak yerine getirmesi mümkün değildir. Erkek ve kadın birbirini tamamlayan iki unsurdur. ${ }^{41}$ Müfessir bu konu hakkında çocuk gelişimi, pedagoji ve rehberlik gibi konulara girerek kadın erkek arasındaki yaratılıştan gelen farklılıklardaki hikmeti araştırmaktadır. Bu bilgiler her ne kadar haddizatında doğru ve kıymetli olsa da bu bilgilere dair düşüncelerini paylaşmanın yeri bu âyetin tefsiri değildir. Zira müfessirin verdiği bu bilgiler âyetin bağlamına uygun düşmemektedir. Mabedin hizmetine erkek çocuk vermeyi adamış, kız çocuğu olunca da üzülmüş bir annenin o esnada insanlığa dönüp cinsiyet farklılığındaki ilahi hikmetleri anlatmaya çalıştığını söylemek pek makul gözükmemektedir.

\section{4. İlgili İbarenin Dil ve Edebiyat Kaynaklarında Ele Alınması}

Zemahşerînnin ilgili ibaredeki zeker ve unsâ kelimelerinin başında yer alan elif lâm takılarının ahd anlamı ifade ettiği ve dolayısıyla da istenilen erkeğin Allah'in verdiği kız gibi olmayacağı yorumu sadece sonraki tefsirlerde değil aynı zamanda dil ve belagat kaynaklarında da kabul görmüş ve ahd konulu başlıklar altında örnek olarak verilmiştir.

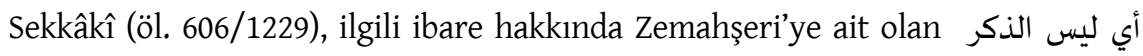
"Senin istediğin erkek sana bahşedilen kız gibi değildir." ifadesini aynen alıntılamıştır. ${ }^{42}$ Aynı ibareye Kazvînî (öl. 739/1338) de yer vermiştir. ${ }^{43}$ Çok az farkla aynı ibare أى ليس الذكر الذى طلبته كالأنثى التى أعطيتها şeklinde el-Alevînnin (öl. 749/1348) Tırâz'ında da geçmektedir. ${ }^{44}$

İbn Hişâm (öl. 761/1360), وَالله أعلم بِمَا وضعت ibaresindeki وضعت kelimesini sükûn üzere وضعت وضعeklinde kıraat edilmesiyle iki cümlenin itiraziyye (ara cümlesi) olacağını ifade etmiştir. Buna göre Hanna, "Kız doğurdum” deyince ara cümleleri olarak "Allah onun ne doğurduğunu daha iyi bilendir ve erkek de kız gibi değildir." söylenmiştir. Dolayısıyla bu itiraziyye cümleleri Allah'a aittir ve anlamı da şu şe-

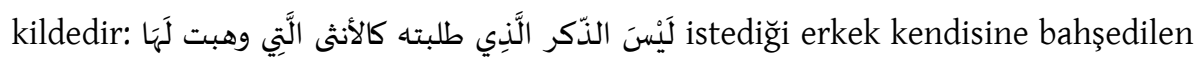
k1z gibi değildir. ${ }^{45}$ Görüldüğü gibi İbn Hişâm da hemen hemen benzer ifadelerle

${ }^{41}$ Muhammed el-Mekkî en-Nâsırî, et-Teysîr fi ehâdîsi't-tefsîr (Beyrut: Dâru'l-Garbi'l-İslâmî, 1985), 1/220.

${ }^{42}$ Ebû Ya'kūb Sirâcüddîn Yûsuf b. Ebî Bekr (b.) Muhammed b. Alî el-Hârizmî es-Sekkâkî, Miftâhu'l-ulûm (Beyrut: Dâru'l-Kutubi'l-ilmiyye, 1987), 215.

${ }^{43}$ Ebü'l-Meâlî Celâlüddîn el-Hatîb Muhammed b. Abdirrahmân b. Ömer b. Ahmed el-Kazvînî, el-Îzâh fi ulûmi'l-belâga, thk. Muhammed Abdülmun'im (Beyrut: Dâru'l-Cîl, ts.), 2/22.

${ }^{44}$ Ebû İdrîs el-İmâm el-Müeyyed-Billâh Yahyâ b. Hamza b. Alî b. İbrâhîm el-Hüseynî el-Alevî, et-Tirâz liesrâri'l-belâga (Beyrut: Mektebetu'l-Unsuriyye, 1423), 3/147.

45 Ebû Muhammed Cemâlüddîn Abdullāh b. Yûsuf b. Ahmed b. Abdillâh b. Hişâm, Mugnni'-lebîb 'an kütübi'le'ârîb, thk. Mâzin el-Mübârek-Muhammed Alî Hamdullâh (Şam: Dâru'l-Fikr, 1985), 514 
Zemahşerî̀nin yaptı̆̆ı tespite atıfta bulunmuştur. Hatta İbn Hişâm bu yorumu değil ama iki cümlenin itiraziyye olduğuna dair görüşü ismini vererek Zemahşerîye dayandırmıştır.

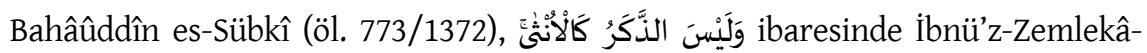
nî̀nin (öl. 727/1327) teşbih-i maklûb ${ }^{46}$ olduğu yönündeki görüşünü nakletmiş ve ona

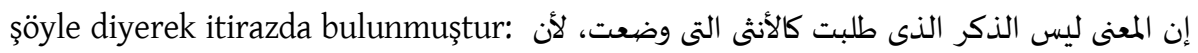
الأنث أفضل منه "Anlaml; senin istediğin erkek doğurduğun bu kız gibi değildir. Zira kız ondan daha üstündür."

\section{Değerlendirme ve Sonuç}

Bazı âyetler, kaçınılmaz olarak farklı anlaşılmaktadır. Bu çalışmada üzerine

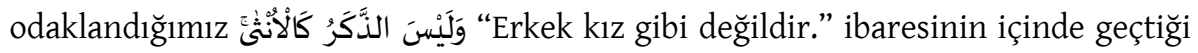
Âl-i İmrân 36. âyeti, bu mecburiyetin bir örneğidir. Şöyle ki bazı nahiv alimleri ibaresini ikinci bir itiraziyye cümlesi olarak ele almaya çalışırken bazıları da itiraz edip şu ifadelere yer vermektedir: İki itiraziyye cümlesi olamaz şeklinde itiraz etmiştir. Bu cümlenin Allah'a ait olduğunu ve dolayısıyla mananın muhakkak bir surette doğan kız çocuğunun üstünlüğüne delalet ettiği kabul edildiği takdirde bu kez de kıraat imamları İbn Âmir, Âsım ve Ya'kûb karşı çıkıyor ve imanı farz olan mütevatir bir kıraati naklediyor: وَالله أعلم بِمَا وضعت Bu kıraate göre ibare Hanne'ya aittir ve tahassür bildirir. Yakın dönem bazı müfessirler, ibareyi kendilerinden emin bir dille erkek değil de Hz. Meryem lehine tefsir ettiklerinde tefsir otoritesi Katâde, İkrime ve Süddî gibi isimler itiraz ediyor ve Beytü'l-Makdis'te hizmet erkeklerin işidir diyor. İbareden erkeğin üstünlüğü kastedilmişse neden nefiyden sonra erkek (müşebbeh), teşbih edatından sonra kız (müşebbehun bih) gelmiş denilirse bu kez de şöyle bir itiraz geliyor: Hanne’nın gönlü ve zihni erkeğe odaklandığı için erkeği takdim etti. Bu, meânî ilmi açısından makul bir yorum gibi görünmektedir. Dolayısıyla şöyle bir sonuca varmış bulunuyoruz: Âyet, kendi manasını keşfetmeye çalışan müfessirlerin her birinin yorumuna açık kalmıştır. Bizim tercihimiz ise ibarenin Allah'a veya Hanne'ye ait olabileceği ve her iki durumda da "teslimiyet dersi" verildiğidir. Hz. Meryem'in annesinin, gönlünde erkek çocuğu olduğu halde kız doğurduğunda Allah'ın takdirine teslimiyet göstermesi ve kendisine bahşedilen kız çocuğunda büyük bir hayır var olduğuna inandığını belirtmesi Kur'ân'ın "tevhît ve tevekkül” maksadına daha uygundur. Zira Kur'ân başından sonuna kadar defalarca kazaya rıza, Allah'ın lütfuna teslim dersi vermiştir. Erkek beklerken kızı olan bir kadının erkek çocuğunun herhangi bir sebeple daha meziyetli olduğu gibi bir düşüncesini yahut tahassürünü Kur'ân'ın bizlerle paylaşmış olması da muhtemeldir. Fakat bizim tercihimiz bu değildir.

${ }^{46}$ Müşebbeh ve müşebbehun bihin yer değiştirerek benzetmede mübalağa sağlanan bir teşbih türüdür.

47 Ebû Hâmid Bahâüddîn Ahmed b. Alî b. Abdilkâfî el-Misrî es-Subkî, Arûsu'l-efrâh fi şerhi telhîsi'l-miftâh, thk. Abdülhamîd Hindâvî (Beyrut: Mektebetu'l-Asriyye, 2003), 2/85. 


\section{Kaynakça}

Alevî, Ebû İdrîs el-İmâm el-Müeyyed-Billâh Yahyâ b. Hamza. et-Tirâz li-esrâri'l-belâga. 3 Cilt. Beyrut: Mektebetu'l-Unsuriyye, 1423.

Bağdâdî, Safiyyuddîn Abdülmü'min b. Abdilhak. Kavâidu'l-usûl ve me'âkidu'l-fusûl muhtasaru tahkîki'l-emeli fì 'ilmeyi'l-usûli ve'l-cedel. thk. Enes b. Âdil ve Abdülaziz b. Adnân. Kuveyt: Dâru'r-Rekâiz, 1439/2018.

Beğavî, Ebû Muhammed. Me'âlimü't-tenzîl. thk. Osmân Cuma. 8 Cilt. Beyrut: Dâru İhyâi'tTurâsi'l-Arabi, 1997.

Beyzâvî, Nâsırüddîn Ebû Saîd (Ebû Muhammed) Abdullāh b. Ömer b. Muhammed. Envâru'ttenzîl ve esrâru't-te'vîl. thk. Muhammed Abdurrahman. 5 Cilt. Beyrut: Dâru İhyâi't-Turâsi'lArabî, 1418.

Buhârî, Abdülaziz b. Ahmed b. Muhammed Alâuddîn. Keşfu'l-esrâr şerhu Usûli'l-Bezdevî. Beyrut: Dâru'l-Kitâbi'l-İslâmî, ts.

Debûsî, Ebû Zeyd Abdullah b. Ömer b. İsa. Takvîmu'l-edille fî usûli'l-fikh. thk. Halil Muhyiddîn elMeys. Beyrut: Dâru'l-Kütübi'l-'ilmiyye, 1421/2001.

Endelusî, Ebû Hayyân Muhammed b. Yûsuf b. Alî b. Yûsuf b. Hayyân. el-Bahrü'l-muhịṭ. thk. Sitkî Muhammed Cemîl. 10 Cilt. Beyrut: Dâru'l-Fikr, 1420.

Eşmûnî, Ahmed b. Abdülkerîm. Menâru'l-Hüdâ fî beyâni'l-vakfi ve'l-ibtidâ. thk. Şerîf Ebu'l-Alâ. Beyrut: Dâru'l-Kutubi'l-ïlmiyye, 2002.

Halebî, Ebü'l-Abbâs Şihâbüddîn Ahmed b. Yûsuf b. İbrâhîm (Abdiddâim). ed-Düreru'l-masûn. thk. Ahmed Muhammed el-Harrâd. 10 Cilt. Şam: Dâru'l-Kalem, ts.

Hatîb, Abdülkerîm Yûnus. et-Tefsîru'l-Kur'ân li'l-Kur'ân. 16 Cilt. Kahire: Dâru'l-Fikri'l-Arabî, ts. Hâzin, Alîb. Muhammed. Lübâbü't-te'vîlfîme'âni't-tenzîl. 4 Cilt. Beyrut: Dâru'l-Kutubi'l-ilmiyye, 1415.

İbn Acîbe, Ebü'l-Abbâs Ahmed. el-Bahrï̈l-medîd fî tefsîri'l-Kur ânin'l-mecîd. thk. Ahmed Abdullah el-Kureşî. 7 Cilt. Beyrut: Dâru'l-Kutubi'l-i̇lmiyye, 2002.

İbn Hişâm, Ebû Muhammed Cemâlüddîn Abdülmelik. Mugni'l-lebîb 'an kütübi'l-e ârîb. thk. Mâzin el-Mübârek-Muhammed Alî Hamdullâh. Şam: Dâru'l-Fikr, 1985.

İbn Kesîr, Ebu'l-Fidâ İsmâil. Tefsîru İbn Kesîr. thk. Muhammed Huseyn Şemsuddîn. 9 Cilt. Beyrut: Dâru'l-Kutubi'l-illmiyye, 1419.

İbn Kuteybe, Ebû Muhammed Abdullāh b. Müslim b. Kuteybe ed-Dîneverî. Garîbi'l-Kur'ân. thk. Ahmed Sakr. Beyrut: Dâru'l-Kutubi'l-ilmiyye, ts.

İbn Kuteybe, Ebû Muhammed Abdullāh b. Müslim b. Kuteybe ed-Dîneverî. Te’vîlu müşkili'lKur'ân. Kahire: Dâru't-Turâs, 1973.

İbnü'l-Cevzî, Ebü'l-Ferec Cemâlüddîn Abdurrahmân. Zâdu'l-Mesîr. thk. Abdürrezzâk el-Mehdî. 4 Cilt. Beyrut: Dâru'l-Kitâbi'l-Arabî, 1422.

İbnü'l-Enbârî, Muhammed b. Kâsım Ebû Bekr. Îdâhu'l-vakfi ve'l-ibtidâ. thk. Muhyiddîn Abdurrahmân Ramadân. 2 Cilt. Şam: Matbaatu Mecmau'l-Lugati'l-Arabiyye, 1971.

İbnü'l-Mulakkın, Ebû Hafs. Şevâhidü't-tavzîh fi şerhhi'l-Câmi'i'ș-șaḥ̂hh. 33 Cilt. Şam: Dâru'n-Nevâdir, 2008.

Râgıb el-İsfâhânî. Tefsîru'r- Râgıb el-İsfâhânî. thk. Âdil b. Alî. 5 Cilt. Riyâd: Dâru'l-Vatan, 2003.

Kazvînî, Hatîb. el-îzâh fí ulûmi'l-belâga. thk. Muhammed Abdülmun'im. 3 Cilt. Beyrut: Dâru'l-Cîl, ts.

Mat'anî, Abdülazîm. Hasâisu't-ta'bîri'l-Kur'ânî. 2 Cilt. Mısır: Mektebetu Vehbe, 1992.

Mâtürîdî, Ebû Mansûr Muhammed b. Muhammed b. Mahmûd. Te'vîlâtu Ehli's-Sunne. thk. Mecdî Beslûm. 10 Cilt. Beyrut: Dâru'l-Kutubi'l-ïlmiyye, 2005.

Mâverdî, Ebü'l-Hasen Alî b. Muhammed b. Habîb el-Basrî el-Mâverdî. en-Nüketu ve'l-uyûn. thk. Es-Seyyid Abdülmaksûd b. Abdurrahîm. 6 Cilt. Beyrut: Dâru'l-Kutubi'l-i̇lmiyye, ts. 
Mekkî b. Ebî Tâlib, Muhammed b. Alî b. Atıyye el-Mekkî el-Acemî. el-Hidâye ilâ bulûğin-nihâye, thk. Heyet. Şârika: mecmûmatu Buhûsi'l-Kitâbi ve's-Sunne, 2008.

Nâsırî, Muhammed Mekkî. et-Teysîr fi ehâdîsi't-tefsîr. 6 Cilt. (Beyrut: Dâru'l-Garbi'l-İslâmî, 1985), $1 / 220$.

Nîsâbûrî, Nizâmüddîn Hasen b. Muhammed b. Hüseyn el-A'rec. Garâibu'l-Kur'ân. thk. Zekeriyyâ Umeyrât. 6 Cilt. Beyrut: Dâru'l-Kutubi'l-ilmiyye, 1416.

Râzî, Ebû Abdillâh (Ebü'l-Fazl) Fahrüddîn Muhammed. Mefâtihu'l-gayb. 33 Cilt. Beyrut: Dâru İhyâi't-Turâsi'l-Arabî, 1420.

Râzî, İbn Ebî Hâtim. Tefsîrül-Kur ânni'l-'azîm. thk. Es'ad Muhammed et-Tayyib. Arabistan: Mektebetu Nizâr Mustafâ el-Bâz.

Reşid Rızâ, Muhammed. Tefsiru'l-menâr. 12 Cilt. Mısır: el-heyetu'l- Mısriyye, 1990.

Seâlibî, Ebû Zeyd Abdurrahmân b. Muhammed b. Mahlûf. el-Cevâhirü'l-hisân fî tefsîri'l-Kurưân. thk. Şeyh Muhammed Alî. 5 Cilt. Beyrut: Dâru İhyâi't-Turâsi'l-Arabî, 1418.

Sekkâkî, Ebû Ya'kūb Sirâcüddîn Yûsuf b. Ebî Bekr (b.) Muhammed b. Alî el-Hârizmî. Miftâhu'lulûm. Beyrut: Dâru'l-Kutubi'l-ìlmiyye, 1987.

Semerkandî, Ebu'l-Leys. Bahru'l-ulûm. thk. Ali Muhammed Mu'avvad, Adil Ahmed Abdülmevcûd ve Zekeriyyâ Abdülmecîd en-Nûtî. 3 Cilt. Beyrut: Dâru'l-Kütübi'l-'illmiyye, 1413/1993.

Sem'ânî, Ebü'l-Muzaffer. Tefsîru'l-Kur'ân. thk. Yasir b. İbrâhîm. Riyâd: Dâru'l-Vatan, 1997.

Serahsî, Muhammed b. Ahmed b. Ebî Sehl Şemsü'l-Eimme. Usûlü's-Serahsî. 2 Cilt. Beyrut: Dâru'lMa'rife, ts.

Siğnâkî, el-Hüseyn b. Ali b. Haccâc b. Ali Hüsâmüddîn. el-Kâfi şerhu'l-Bezdevî. thk. Fahruddîn Seyyid Muhammed Kānit. 5 Cilt. Beyrut: Mektebetü’r-Rüşd, 1422/2001.

Sübkî, Ebû Hâmid Bahâüddîn Ahmed b. Alî b. Abdilkâfî el-Misrî. Arûsu'l-efrâh fî şerhi telhîsi'lmiftâh. thk. Abdülhamîd Hindâvî. 2 Cilt. Beyrut: Mektebetu'l-Asriyye, 2003.

Süyûtî, Ebü’l-Fazl Celâlüddîn Abdurrahmân b. Ebî Bekr b. Muhammed el-Hudayrî. el-ittkân fî ulûmi'l-Kur'ân. thk. Muhammed Ebu'l-Fadl İbrâhîm. 4 Cilt. Mısır: el-Hey'etu'l-Misriyye, 1974.

Şa'râvî, Muhammed Mütevelli. Tefsîru'ş-Şa'râvî. Mısır: Ahbâru'l-Yevm, 1991.

Şâşî, Ebû Ali Ahmed b. Muhammed b. İshak Nizâmuddîn. Usûlü'ş-Şâşî. Beyrut: Dâru'l-Kitâbi'l'Arabî, ts.

Şevkânî, Ebû Abdillâh Muhammed b. Alî b. Muhammed es-San'ânî el-Yemenî. Fethu'l-Kadîr. 6 Cilt. Şam: Dâru İbn Kesîr, 1414.

Taberi, Ebû Ca‘fer Muhammed b. Cerîr b. Yezîd el-Âmülî et-Taberî el-Bağdâdî. Câmiu'l-beyân. thk. Ahmed Muhammed Şâkir. 24 Cilt. Beyrut: Muessesetu'r-Risâle, 2000.

Vâhidî, Ebü'l-Hasen Alî b. Ahmed b. Muhammed en-Nîsâbûrî. el-Vecîz fì tefsîril'-kitâbi'l-‘aziz. thk. Safvân Adnân Dâvûdî. Şam: Dâru'ş-Şâmiyye, 1415.

Zemahşerî, Ebü'l-Kāsım Mahmûd b. Ömer b. Muhammed el-Hârizmî. el-Keşşâf 'an hakāikịı ġavâmizì't-tenzîl ve 'uyûni'l-ekāvîl fî vücûhi't-te'vîl. Beyrut: Dâru'l-Kutubi'l-Arabî, 1407.

Zerkeşî, Ebû Abdillâh Bedrüddîn Muhammed b. Bahâdır b. Abdillâh et-Türkî el-Mısrî elMinhâcî eş-Şâfiî. el-Burhân fî 'ulûmi'l-Kur ân. thk. Muhammed Ebu'l-Fadl İbrâhîm. 4 Cilt. Beyrut: Dâru İhyâi'l-Kutubi'l-Arabiyye, 1967. 